3. Активное применение законодателем в 1960-1996гг. административной преюдиции в советском уголовном праве подтверждает эффективность данного правового института.

4. Практика применения в 1922-1996гг. административной преюдиции в отечественном уголовном праве является фундаментом для обоснования необходимости его применения в действующем уголовном законодательстве России.

$$
* * *
$$

1. Кацва Л.А. История России. Советский период. (1917-1991). М.: РГУ, 2003.

2. Комиссарова В.С. Российское уголовное право. Общая часть. СПб., 2005.

3. Кузнецова Н.Ф., Тяжкова И.М.. Курс уголовного права. Том 1: Учение о преступлении. М., 2002.

4. Бастрыкин А.И., Наумов А.В. Уголовное право России. Практический курс. 3-е изд., перераб. И доп. M., 2007.

5. Курилов С.И. Научные подходы к исследованию уголовно-правовой природы компромисса // Закон и право. Изд. «ЮНИТИ-ДАНА». 2015. №09. С.94-96.

6. Юнусов А.А. Серкова Т.В. Административная преюдиция в российском уголовном праве // Актуальные проблемы экономики и права. 2015. №1 (33). С. 278-282.

7. URL:http://www.libussr.ru/doc_ussr/ussr_2277.htm (дата обращения 16.10.2017).

8. Воронин М.Ю. Криминологические проблемы правоохранительной деятельности // Труды Академии управления МВД России. 2016. №1. С.70-74.

9. Аносов А.В. Особенности индивидуального предупреждения соучастия несовершеннолетних в преступлении // Труды Академии управления МВД России. 2015. №3. С.36-40.

10. Мартыненко Н.Э. Совершенствование уголовно-правовой охраны потерпевшего- задача уголовной политики Российской Федерации // Труды Академии управления МВД России. 2014. №4. С.10-13.

11. Стенограмма заседания президиума Государственного совета «О состоянии уголовноисполнительной системы Российской Федерации» от 11.02.20109 года. URL http://www.kremlin.ru/events/state-council/3151.

\title{
Курилов С.И. \\ Значение норм и институтов Общей части УК России в общей и специальной превенции уголовно-правового предупреждения преступлений
}

Академия управления МВД России

(Россия, Москва)

doi:10.18411/spc-22-11-2017-20

idsp: 000001:spc-22-11-2017-20

Предупреждение преступлений - является одной из задач Уголовного кодекса Российской Федерации, которая регламентируется ч. 1 ст. 2 УК России.

Вместе с тем предупреждение совершения новых преступлений, является одной из функций уголовного права, которая получила свое закрепление в ч. 2 ст. 43 УК России.В этой части указанной нами статьи говориться о том, что цель наказания предупреждение совершение новых преступлений наряду с восстановлением социальной справедливостью, а так же исправления осужденных.

Таким образом, можно предположить, что законодатель по разному сформулировал задачу УК России - предупреждение преступлений и цель наказания предупреждения совершения новых преступлений, в связи с тем, что наказание может быть назначено только за совершенное преступление. Совершенное преступление, выступает в качестве уже совершившегося факта, поэтому перед УК и ставиться цель предупреждения совершения новых преступлений, в первую очередь со стороны осужденного, а заодно и со стороны иных граждан. Содержание же предупреждение преступлений, как задачи УК России, охватывает предупреждение преступлений со стороны граждан, т.е. первичных преступлений, а затем если они совершены, то и рецидивных преступлений, т.к. одним из направлений ее решения является достижения цели наказания, т.е. как нами было отмечено ранее - предупреждения новых преступлений. 
Хотелось бы заметить, что нельзя сводить предупредительную функцию уголовного права только к действию санкции уголовно-правовойнормы, т.к. не только уголовное наказание обладает предупредительной способностью. В предупреждении преступлений и противодействию преступности наказание по нашему мнению не является единственным средством превенции.

В научной литературе под общей превенцией понимается - уголовно-правовое воздействие на сознание неустойчивых граждан (общепредупредительное воздействие)[3].Суть общей превенции заключается в удержании граждан от совершения преступлений, т.е. в предупреждении преступлений со стороны лиц ранее их не совершавших.

Под специальной превенцией понимается уголовно-правовое воздействие на лиц, совершивших преступления (частнопредупредительное воздействие) [3]. Суть специальной превенции заключается, в том, что бы ни допустить нового преступления со стороны указанных лиц, т.е. в предупреждении повторного их совершения.

Под уголовно-правовым предупреждением понимается - предупредительное воздействие уголовной ответственности и наказания и других средств уголовного закона на определенные криминогенные факторы, реализуемые в специальной деятельности ее субъектов [В.С. Устинов С. 49.]

Важное значением в общей и специальной превенции имеет, то, что предупреждение преступлений осуществляется при помощи средств уголовного закона, одними из которых являются нормы,и институты Общей части УК России.

Так, например, условно-досрочное освобождение от отбытия наказания (ст. 79 УК России) или замена неотбытой части наказания более мягким видом наказания (ст. 80 УК России) могут быть применены к осужденному лишь в том случае, если он возместил вред (полностью или частично), причиненный преступлением и примерным поведением доказал свое исправление. Перечисленные условия, несомненно, побуждают осужденное лицо к воздержанию от различных преступлений и правонарушений.

Так же вышеуказанные нормы обладают превенцией уголовно-правового предупреждения на всех стадиях развития преступной деятельности - приготовления, покушения и оконченного преступления. Так, например значительное предупредительное значение имеет ст. 31 УК России, согласно которой лицо не подлежит уголовной ответственности на стадиях приготовления и покушения на преступление, если оно добровольно и окончательно от доведения этого преступления до конца. Указанная статья образует правовую основу для предотвращения дальнейшей общественно опасной деятельности путем склонения к добровольному отказу от ее продолжения.

Большое предупредительное значение имеет тот факт, когда лицу предоставляется возможность свободно распоряжаться, в известных рамках, своими правами, выбрать тот или иной вариант поведения. Вышеуказанный вариант возможен, когда лицо имеет право явиться с повинной в органы власти. В данном случае оно не обязывается, а побуждается к явке с повинной путем обещания поощрения - смягчения наказания (п. и ч.1 ст. 61 УК России) или освобождается от уголовной ответственности (примечание к ст. 275 УК России) и др.

Некоторые виды деятельного раскаяния в случаях, специально предусмотренного нормами Особенной части УК России, влекут за собой обязательной освобождение от уголовной ответственности (ст. 75УК России, примечания к ст.ст. ст.126, 127.1 , 178, 184, 198, 199, 204, 205, 205.1, 205.3, 205.4, 205.5, 206, 208, 210, 222, $222.1,223,223.1,228,228.3,275,282.1,282.2,282.3,284.1,291,291.1,307)$. Так, например, освобождение от уголовной ответственности взяткодателей по причине добровольного сообщения о случившемся органу, имеющему право возбудить 
уголовное дело, способствует предупреждению совершения новых преступлений со стороны должностных лиц (примечание к ст. 291 УК России) и др.

Таким образом, мы присоединяемся к мнению специалистов, которые считают, что как общую, так и специальную (частную) превенцию уголовного закона детерминируют так называемые нормы и институты, непосредственно направленные на предупреждение преступлений, касающиеся стадий неоконченного преступления и добровольного отказа от совершения преступления, обстоятельств исключающих преступность деяния, освобождения от уголовной ответственности, некоторых видов освобождения лица от наказания и смягчение наказания $[1 ; 2 ; 5 ; 6]$.

В связи с этим, можно сделать вывод, что значение норм и институтов Общей части УК России в уголовно-правовом предупреждении заключается в том, что в них нет прямого указания об их предупредительной роли, однако ими регулируется фактическое предупреждение преступлений, т.к. они обладают потенциалом как общей, так и специальной превенции.

$$
* * *
$$

1. Богданов А.В. Административнаяпреюдиция в уголовном законодательстве России // Сборник статей по материалам VI Международной научно-практической конференции «Научные тенденции: Юрисприденция» 20.06.20017г. Изд. ЦНК МНИФ «Общественная наука». М. 2017 г. С.4-6.

2. Осипов И.В. Возможность эффективной защиты экономических интересов как фактор социальной обусловленности уголовно-правовых мер воздействия в сфере экономической деятельности // Сборник статей по материалам VI Международной научно-практической конференции «Научные тенденции: Юрисприденция» 20.06.20017 г. Изд. ЦНК МНИФ «Общественная наука». М. 2017г. C.36-38.

3. СаркисоваЭ.А.Предупредительная роль уголовного закона.Минск, 1979. С.21.

4. Устинов В.С.Система предупредительного воздействия на преступность и уголовно-правовая профилактика. М., 1983. С.49

5. Цепелев В.Ф. Основные направления научных исследований кафедры уголовно-правовых дисциплин и организации профилактики преступлений Академии управления МВД России//Российский следователь, 2009, N 15 C.4.

6. Чумичкин А.С. Уголовно-правовая защита сотрудников внутренних дел, в связи с выполнением ими служебного долга // Сборник статей по материалам V Международной научно-практической конференции «Научные тенденции: Юрисприденция» 20.05.20017г. Изд. ЦНК МНИФ «Общественная наука». М. 2017 г. С.32-37.

\section{Михайлова К.М. \\ Усыновление (удочерение) по семейному законодательству России}

Кубанский государственный аграрный университет им. И.Т. Трубилина

(Россия, Краснодар)

doi:10.18411/spc-22-11-2017-21

idsp: 000001:spc-22-11-2017-21

Усыновление представляет собой правовой институт, призванный создать между усыновителем и усыновленным отношения, наиболее близкие к тем, которые возникают между родителями и кровными детьми. По семейному законодательству РФ усыновление или удочерение (далее для удобства будет использовать только усыновление) является приоритетной формой устройства детей, оставшихся без попечения родителей (п. 1 ст. 124 СК РФ). Усыновление допускается в отношении несовершеннолетних детей и только в их интересах с соблюдением требований абз. 3 п. 1 ст. 123 СК РФ.

В настоящее время в мире находится много семей, которые лишены радости материнства или отцовства, по разным причинам: утрата ребенка, или невозможность иметь своих детей в силу болезни, и т.д. Государство в свою очередь помогает таким семьям, предоставляя возможность обрести ребенка путем усыновления (удочерения). 